\title{
Analysis of Activity Efficiency of Private Pension Fund at Regional Level
}

\author{
Irina K. Bitkina* \\ Volgograd Institute of Management, Branch of the Russian Presidential Academy of National Economy and Public Administration \\ under the President of the Russian Federation, Gagarina, 8, 400131, Volgograd, Russia
}

\begin{abstract}
The presented study is devoted to an analysis of activity of private pension funds at the regional level. Results connected with generalization of the available theoretical developments in selected thesis of the study are shown in the article. There is also the author's approach to the evidence of efficiency of private pension funds estimation and practical conclusions on estimations of efficiency of activity of regional private pension funds in south federal neighborhood.
\end{abstract}

\section{Introduction}

Social security is one of the basic tasks of each state, which includes social defence, social aids and social insurance. The latter includes pension insurance [1]. It influences the income level of the essential part of pensioners, financial efficiency of the national pension system, which shows the ability of the state pension fund to make its own obligations using available income sources without borrowing some external means.

These tasks will be solved when a pension model is based on insurance principles. Such model has been used in Russia since 2002 [2]. This model originated from the pension reform; the main aim of it was construction of the financial stability pension system, providing highlevel standards of pensioners' life. For this aim there was made a lot: 1) changing of the institutional structure; 2) developing of the financial mechanism of the pension system; 3) changing of conditions of forming pension rules (pension earnings).

A funded method of financing is an alternative solution to this problem, which is used together with the distribution mechanism in the pension systems of a number of countries [3]. It was assumed that this step would significantly increase the degree of independence of the pension system on the dynamics of foreign markets. The emergence of this mechanism has subsequently led to a change in the institutional structure of the pension system, in which private pension funds, as well as a number of additional voluntary pension insurance institutions, play a significant role alongside public pension funds [4].

The increasing of role of voluntary pension savings in the total pension income level is one of basic ways of reforming the Russian pension system. It is clear that this task realization is impossible without an effective development of private pension funds, which is an essential element of a credit-financial system [5].
In fact, the pension funds are an essential part of the national financial market. By the OECD data, nowadays approximately $28 \%$ of the general sum of investment resources are the pension funds sources, including private pension funds [6]. And this proportion is increasing all the time.

It should be noted that the above-mentioned pension institutions are not homogeneous and include state pension funds and private pension funds [7]. The division of existing pension institutions into private and public ones is based on national regulatory requirements, peculiarities of financial regulation, requirements for the structure of the investment portfolio and performance indicators of its formation [8].

These differences among the national pension funds as financial market institutions appear as a historical feature such as a result of long evolution of the national pension security system.

The aim of this thesis is an analysis of efficiency of private pension funds activity based on the author's approach.

\section{Data for study and research methods}

The theoretic base of the thesis is founded on Russian and foreign economists' articles devoted to an efficiency of financial organizations activity and an estimate of the Russian pension system trends development. The empiric base consists of the official public account of private pension funds, which is situated in south federal neighborhood (2010-2013): analytic materials and recommendations of OECD, the Pension Fund of Russia, International Labour Organization. Development of practical recommendations is impossible without studying the theory of the question. A fairly extensive list of literature is devoted to pension issues today [9]. Theoretical and practical questions of social and pension insurance, pension system development of the state and

\footnotetext{
*Corresponding author: bitkinai@rambler.ru
} 
reform explored in the writings of leading domestic and foreign economists: Antropova, V. V., Baskakov I. V., Batanova, G. N., Borisenko N. Yu., Brodsky, M. N., Willmore L., Munizaga V. I., Degtyarev G. P., Dmitriev E. M., Krylova E. K., Lazarev A. A., Lvov D. S., Merton S., Morozova O. S., Rashid M., ROCA D. V., Sergeeva T. Yu., Sinyavsky O. V., Solovyov A. K., Travin D. J., Khmyz O. V., Chernysheva L. N., Yanenko E. A., and others. Work on the analysis of international experience with pension reforms belongs to a separate group (Borisenko N. Yu., Khmyz O. V., L. Willmer, etc.). The historical aspects of the pension system development can be traced in the works of Astrakhan E. I., Dmitriev M. E., Degtyarev G. P. and other authors. Conceptual bases of development of pension systems are presented in works of Gontmakher E. Sh., Roik V. D., Sinyavskaya O. V., Solovyov A. K., Yassin E. G. We should also highlight the development forecasts of the Russian pension system. These are actuarial forecasts of Soloviev A.K., a model of the pension system by Baskakov V.N., Lelchuk A. L., Yanenko E. A. Economic and financial forecast of the Federation Council of the Russian Federation is prepared by the World Bank model of pension system development by Pomazkin D. V. and Martino K. Prediction is developed in the framework of the TACIS project, the options of reforming the system of mandatory pension insurance.

Despite a rather large number of works devoted to this subject, a number of questions remain not fully investigated. These include the problems associated with non-equivalent accounting of pension rights of certain categories of pensioners, the presence of non-insurance elements in the system of compulsory pension insurance, the correlation of different options for the development of the pension system of Russia, the development of criteria for their effectiveness and efficiency in various aspects of pension reform. The issues concerning institutional development of the country's pension model remain insufficiently investigated. The above-mentioned problems have defined the structure of this research project.

Currently, there are quite a number of developments in the domestic financial science devoted to the methodological foundations of performance evaluation.

These works contain recommendations on the composition of indicators and performance criteria, its terminology definition, types, methods of evaluation, that is, a description of the concept of the effectiveness of different areas of the economy. At the same time, it should be noted that with regard to pension insurance at the present time, the concept of performance assessment remains practically undeveloped, which determines the need for a study of this direction.

\section{Results and discussion}

Pension systems are the most important elements of income and social protection systems, and their resources are among the most important in the financial markets. In this regard, when assessing the performance of national pension systems, analysts usually pay attention, first of all, to three aspects:

1) the level of pension provision for citizens;

2) volume and share of financial resources of the pension system in relation to GDP;

3) financial stability of the pension system.

Such an analysis allows determining the state and prospects of pension provision in a particular country, the place of individual pension institutions, the effectiveness of relevant reforms.

It should be noted that the current domestic research on the financial performance of the pension system touches one of the presented aspects; however, in order to obtain a comprehensive picture of the state of pension provision, it is necessary to take into account the totality of the factors presented.

In order to take into account these factors, it is necessary to refer to the institutional structure of compulsory pension insurance, the study of which was conducted above [10]. It can be noted that from the point of view of the mechanisms and elements used, compulsory pension insurance is at the junction of two spheres - insurance and the budget system, which determines the features of the analysis of the effectiveness and efficiency of its activities.

In order to ensure the effective functioning of the system of compulsory pension insurance, certain requirements must be met when developing the directions of its reformation. The main one is a scientific approach to their development, taking into account the real state of the economy, Finance and budget system of the country. Compulsory pension insurance cannot be effective if its main directions for the nearest period and perspective are not clearly defined, the main goals and priorities are not formulated.

The directions of assessing the effectiveness and efficiency of the functioning of compulsory pension insurance are largely similar to the concept of efficiency and effectiveness in the budget sector of the economy. Improving the efficiency of budget expenditures for the provision of services to society is one of the priorities of the modern policy of budget planning and reform at all levels of the public finance system. The state was responsible for the expenditure commitments it had undertaken and should provide evidence that the budget spent had yielded some results or had been spent with some effect. Moreover, the obtained effects should be sufficiently reliable and confirmed by certain digital values in the directions, articles, programs, projects of budget financing of public needs. Thus, the main problem of the current budget reform is to improve the efficiency of budget expenditures at all levels of the budget system, as this is a more important factor in increasing efficiency in modern conditions compared to its revenue.

Following results are received as a result of conducted studies.

Coming from the generalizations, an available approach to estimation of efficiency to activity of the pension fund makes it possible classify the following sign: 
1. the authors' method, which is represented in Russian and foreign research monographs, articles and thesis;

2. the law and normative way, which is formed for requirements of Russian legislation;

3. the rating agencies' methods, used for arranging private pension funds of comparable ratings;

4. the private pension funds, used for owned investment policy.

Each of presented approaches has their own particularities, connected with methods of the estimation, an information base of the study and target purpose result estimations. Herewith each of approaches has a row of the restrictions, in accordance with interpretation and using result analysis in practice, particularly in a part of the rational choice of the programs private pension funds on the part of users.

Considering a number of features of this part of pension (long-term character of formation, dependence on the financial market, availability of alternative options of investments from both non-state pension funds and other forms of investment), specificity of an assessment of efficiency of its activity is defined.

First, you want to evaluate data sufficiency of pension savings for the formation of pension payments necessary for the formation of pension payments to a certain level.

Secondly, to determine the effectiveness of this part of the pension, it is necessary to monitor the investment instruments of pension savings within the framework of compulsory pension insurance.

At the final stage of the analysis within the framework of this direction, it is necessary to compare the level of profitability of pension savings investment compared to other options of their investment.

For reduction level, restriction data, the author offers a methodical approach, founded on complex estimation of efficiency of activity of private pension funds (table $1)$.

Table 1. The criteria of the estimation of efficiency of activity of private pension funds.

\begin{tabular}{|c|c|c|c|c|}
\hline № & $\begin{array}{l}\text { Name of } \\
\text { the group } \\
\text { of the } \\
\text { factors }\end{array}$ & $\begin{array}{l}\text { Methods of } \\
\text { the } \\
\text { calculation }\end{array}$ & $\begin{array}{l}\text { Group } \\
\text { of the } \\
\text { users, } \\
\text { interest } \\
\text { ed in } \\
\text { specifie } \\
\text { d factor }\end{array}$ & $\begin{array}{l}\text { Economic } \\
\text { interpretatio } \\
\mathrm{n} \text { of the } \\
\text { factors }\end{array}$ \\
\hline 1 & 2 & 2 & 3 & 4 \\
\hline 1 & $\begin{array}{l}\text { Reliability } \\
\text { of a private } \\
\text { pension } \\
\text { fund }\end{array}$ & $\begin{array}{l}\text { Correlation } \\
\text { of the } \\
\text { amount of } \\
\text { the } \\
\text { discharged } \\
\text { facilities to } \\
\text { amount of } \\
\text { the } \\
\text { contributor } \\
y\end{array}$ & $\begin{array}{l}\text { Clients } \\
\text { of } \\
\text { private } \\
\text { pension } \\
\text { funds } \\
\text { (assure } \\
\text { d } \\
\text { person - } \\
\text { a future } \\
\text { grantee }\end{array}$ & $\begin{array}{l}\text { Probability } \\
\text { of the } \\
\text { return the } \\
\text { facilities, } \\
\text { placed } \\
\text { client in a } \\
\text { private } \\
\text { pension } \\
\text { fund, in } \\
\text { equivalent }\end{array}$ \\
\hline
\end{tabular}

\begin{tabular}{|c|c|c|c|c|}
\hline & & \begin{tabular}{ll}
\multicolumn{2}{l}{ accumulatio } \\
ns & for \\
period &
\end{tabular} & $\begin{array}{l}\mathrm{s} \quad \text { to } \\
\text { pension } \\
\mathrm{s})\end{array}$ & volume \\
\hline 2 & $\begin{array}{l}\text { Sufficiency } \\
\text { of the own } \\
\text { facilities of } \\
\text { a private } \\
\text { pension } \\
\text { fund }\end{array}$ & $\begin{array}{l}\text { Correlation } \\
\text { of the own } \\
\text { capital of } \\
\text { the fund to } \\
\text { value its } \\
\text { asset with } \\
\text { provision } \\
\text { for their } \\
\text { level of the } \\
\text { risk }\end{array}$ & $\begin{array}{l}\text { Checki } \\
\mathrm{ng} \\
\text { organs - } \\
\text { founder } \\
\mathrm{s} \text { of a } \\
\text { private } \\
\text { pension } \\
\text { funds }\end{array}$ & $\begin{array}{l}\text { Sufficiency } \\
\text { of the own } \\
\text { capital } \\
\text { private } \\
\text { pension } \\
\text { fund for } \\
\text { performanc } \\
\mathrm{e} \text { of the } \\
\text { obligations } \\
\text { of the fund }\end{array}$ \\
\hline 3 & $\begin{array}{l}\text { Liquidity } \\
\text { of a private } \\
\text { pension } \\
\text { fund }\end{array}$ & $\begin{array}{l}\text { Correlation } \\
\text { asset fund } \\
\text { (with the } \\
\text { period) to } \\
\text { obligations } \\
\text { of the fund } \\
\text { (with the } \\
\text { date of the } \\
\text { performanc } \\
\text { e) }\end{array}$ & $\begin{array}{l}\text { Checki } \\
\text { ng } \\
\text { organs- } \\
\text { founder } \\
\mathrm{s} \text { of the } \\
\text { fund }\end{array}$ & $\begin{array}{l}\text { Degree to } \\
\text { sufficiency } \\
\text { asset fund } \\
\text { for } \\
\text { performing } \\
\text { its function. }\end{array}$ \\
\hline 4 & $\begin{array}{l}\text { Investment } \\
\text { attractiven } \\
\text { ess of a } \\
\text { private } \\
\text { pension } \\
\text { fund }\end{array}$ & $\begin{array}{l}\text { Comparison } \\
\text { income } \\
\text { pension } \\
\text { accumulatio } \\
\text { ns of } \\
\text { private } \\
\text { pension } \\
\text { funds with } \\
\text { factor } \\
\text { financial } \\
\text { market } \\
\text { and/or rate } \\
\text { of inflation } \\
\text { in country }\end{array}$ & $\begin{array}{l}\text { Clients' } \\
\text { private } \\
\text { pension } \\
\text { fund. } \\
\text { Potentia } \\
1 \\
\text { investor } \\
\text { s. } \\
\text { Founde } \\
\text { rs of the } \\
\text { fund. }\end{array}$ & $\begin{array}{l}\text { Level of } \\
\text { income } \\
\text { pension } \\
\text { accumulatio } \\
\text { ns for } \\
\text { similar } \\
\text { factors of } \\
\text { market }\end{array}$ \\
\hline 5 & $\begin{array}{l}\text { Financial } \\
\text { stability of } \\
\text { a private } \\
\text { pension } \\
\text { fund }\end{array}$ & $\begin{array}{l}\text { Correlation } \\
\text { of the own } \\
\text { capital } \\
\text { private } \\
\text { pension } \\
\text { fund }\end{array}$ & $\begin{array}{l}\text { Clients' } \\
\text { private } \\
\text { pension } \\
\text { fund. } \\
\text { Founde } \\
\text { rs of the } \\
\text { fund }\end{array}$ & $\begin{array}{l}\text { The ability } \\
\text { of the } \\
\text { pension } \\
\text { fund to save } \\
\text { its financial } \\
\text { independen } \\
\text { ce from } \\
\text { external of } \\
\text { the } \\
\text { financial } \\
\text { sources at } \\
\text { long-term } \\
\text { period. }\end{array}$ \\
\hline
\end{tabular}

The source: formed by the author

The specified methods allows complex to take into account the particularities to activity regional private pension funds. Designed methods helped to organize analysis of efficiency of activity private pension fund, registered on the territory of south federal neighborhood. A sample has formed 6 private pension funds [10]. 
As a result of analysis the author chose following particularities of activity of specified private pension funds:

1. comparatively low level of financial stability of activity regional private pension funds, given by a growing amount grantees to pensions on private pension provision (the average increase of $8-10 \%$ per annum) under comparatively stable count; calculation; list payer of the dues (the increase is absent, or forms less than $1 \%$ per annum);

2. liquidity of the private pension fund is sufficient for satisfaction current of the obligations, herewith with fixed liabilities there are certain negative trends connected with the problem in achievement of financial stability of the fund. Herewith one can note that beside one of analysed fund there are indebtedness on payment pension, caused external negative factor; the specified circumstance points to available problems with liquidity separate private pension funds.

3. the level of yielded pension accumulations of considered pension funds has a significant deflection, but on average importance of the given factor forms $8,5 \%$ of considered collections that exceeds the level of official inflation in the country. The presented particularity is a feature level of investment attractiveness of the pension accumulations.

The process of financial regulation of investment of pension savings can also be complicated due to the lack of criteria and performance indicators of participants and subjects of the pension savings investment market in the current version of the law. The article of the law on basic concepts and definitions does not define such important criteria for assessing the effectiveness of investment as "profitability" and "risk" of pension savings. There is no legislative description of the algorithm for calculating these indicators and their minimum and maximum threshold values, which complicates the process of regulation in this area.

As the directions of an increase of efficiency of functioning of accumulative pension investment programs in the framework of compulsory pension insurance, in our opinion, the following measures will be the most appropriate.

First of all, in the system of state financial regulation of non-state pension insurance, it seems to us expedient to introduce a number of changes related to the clarification of the regulatory object, the development and refinement of indicators and performance criteria of participants and subjects of the pension savings investment market. Within the framework of this set of measures, we also consider it necessary to eliminate existing shortcomings and improve the system of cofinancing of pension savings in order to increase the attractiveness of this program for potential participants.

Secondly, it seems appropriate to review the procedure for the formation of the portfolio of investment assets. The revision of approaches to the formation of the investment portfolio of pension assets is also an important direction for improving the financial performance of non-state pension insurance in the Russian Federation. Here, in our opinion, it is possible to apply the so-called "life cycle" principle, which assumes that different categories of insured persons, depending on their year of birth, are offered different financial assets for the purpose of investment.

Thus, for the older generation this portfolio will be more conservative, and for the generation that has just started working, it is possible to use high-yield financial instruments with a higher level of risk. As part of this measure, it is advisable to create a system of guaranteeing pension savings by analogy with the system of insurance of Bank deposits, in order to increase the attractiveness of voluntary forms of pension insurance.

The basis for the allocation of these groups, in addition to age characteristics, is especially in the implementation of labor functions. It follows that the allocation of age limits is conditional and may differ for individual potential pension recipients.

On the basis of this, there is a need to establish at least one additional parameter to identify these groups. It is possible for us to choose the criterion of the level of earned income, namely the dynamics of its growth relative to the average level.

Three criteria are included to highlight the characteristics requirements for investment assets included in the investment portfolio:

- yield;

- safety;

- differentiation.

We deliberately omit the risk criterion because it is the opposite of the selected yield criterion. Instead of the risk criterion, it is proposed to use the safety criterion, which formalizes the degree of guarantee of return of these funds at the time of retirement, not only in nominal but also in real terms.

Differentiation involves the possibility of choosing assets that differs, in turn, by the characteristics of safety and profitability. It is expedient to provide an opportunity of independent choice for interested insured persons within both the framework of various assets included on the portfolio and the opportunity of investing in different investment portfolios formed within the framework of different management companies.

\section{References}

1. I. Bitkina, Almanac of the modern science and formation 9, 151-153 (2010)

2. The Pension Fund of the Russian Federation. Retrieved from www.pfrf.ru

3. D. Philip FSA Occasional Paper 15, 1-28 (2001)

4. Pension markets in focus. Retrieved from http://www.oecd.org/finance/pensionmarketsinfocus.htm

5. OECD Working Paper 7, 1-63 (1999)

6. Organisation for Economic Co-operation and Development. Retrieved from www.oecd.org

7. P. Antolin OECD Working Papers on Insurance and Private Pensions 3, 10-17 (2007) 
8. Averting the Old-Age Crisis Policies to Protect the Old and Promote Growth (The World Bank, 1994)

9. I. Bitkina, J. Brechova The Things about pensions since the youth (RANEPA, 2012)

10. The Central Bank of The Russian Federation. Retrieved from www.cbr.ru 